\title{
New horizons of methotrexate application
}

\section{Novi horizonti primene metotreksata}

\section{Vladimir Maksimovic ${ }^{1}$, Svetlana Golocorbin-Kon², Momir Mikov ${ }^{1}$, Jelena Cvejic ${ }^{2}$, Zora Pavlovic Popovic ${ }^{3}$, Sasa Vukmirovic ${ }^{1}$}

1. Department of Pharmacology, Toxicology and Clinical Pharmacology, Faculty of Medicine, University of Novi Sad, Novi Sad, Serbia

2. Department of Pharmacy, Faculty of Medicine, University of Novi Sad, Novi Sad, Serbia

3. Institute of Pulmonary Diseases, Sremska Kamenica, Faculty of Medicine, University of Novi Sad, Novi Sad, Serbia

RECEIVED 26.11.2019.

ACCEPTED 29.02.2020.

\section{ABSTRACT}

Methotrexate is an anti-inflammatory and anticancer drug that has been used in the treatment of various oncological and inflammatory diseases (such as rheumatoid arthritis, inflammatory bowel disease, psoriasis, sarcoidosis, etc.). Scientists are working on finding optimal formulation that will maintain its efficacy and improve safety and nanoparticles have shown to be carriers with great potential as they protect the drug from degradation while at the same time they increase absorption. In vivo and in vitro studies of numerous nanoparticle preparations have showed that they generally have appropriate characteristics and can be carriers for targeted delivery of methotrexate to the tissues affected by disease. Topical preparations of methotrexate, mainly for the treatment of psoriasis, have also been assessed in various research and have showed promising results. Further research is warranted by the obtained results and will hopefully lead to new methotrexate formulations that will be approved by regulatory authorities and used instead of existing ones to improve efficacy of the drug and patients' safety.

Key words: methotrexate; inflammation; administration, topical; nanoparticles; pharmaceutical preparations.

\author{
Vladimir Maksimović ${ }^{1}$, Svetlana Goločorbin-Kon², \\ Momir Mikov ${ }^{1}$, Jelena Cvejićc ${ }^{2}$ Zora Pavlović Popovićz, \\ Saša Vukmirović ${ }^{1}$ \\ 1. Zavod za farmakologiju, toksikologiju i kliničku farmakologiju, Medicinski \\ fakultet, Univerzitet u Novom Sadu, Novi Sad \\ 2. Odsek za farmaciju, Medicinski fakultet, Univerzitet u Novom Sadu, Novi Sad \\ 3. Institut za plućne bolesti, Sremska Kamenica, Medicinski fakultet, Univerzitet u \\ Novom Sadu, Novi Sad
}

PRIMLJEN 26.11.2019.

PRIHVAĆEN 29.02.2020.

\section{APSTRAKT}

Metotreksat je antiinflamatorni i antineoplastični lek koji se koristi u lečenju različitih onkoloških i inflamatornih bolesti (poput reumatoidnog artritisa, zapaljenskih bolesti creva, psorijaze, sarkoidoze itd.). Naučnici rade na pronalaženju optimalne formulacije koja će zadržati efikasnost i poboljšati sigurnost, a nanočestice su se pokazale kao nosioci sa velikim potencijalom, jer štite lek od razgradnje, a istovremeno povećavaju apsorpciju. Studije in vivo i in vitro brojnih preparata nanočestica pokazale su da generalno imaju odgovarajuće karakteristike i mogu biti nosioci ciljane isporuke metotreksata tkivima koja su pogođena bolestima. Lokalni preparati metotreksata, uglavnom za lečenje psorijaze, takođe su ispitivani u raznim istraživanjima i pokazali su obećavajuće rezultate. Dalja istraživanja su opravdana do sada dobijenim rezultatima i nada je da će dovesti do novih formulacija metotreksata koje će odobriti regulatorna tela i koja će se koristiti umesto postojećih za poboljšanje efikasnosti leka i bezbednosti pacijenata.

Ključne reči: metotreksat; zapaljenje; primena, lokalna; nanočestice; farmaceutski preparati. 


\section{INTRODUCTION}

Methotrexate (MTX) is an anti-inflammatory and anticancer drug that has been widely used for the past 50 years. Anticancer effect is explained by folate antagonism, as MTX is a competitive inhibitor of , preventing regeneration from dihydrofolate to tetrahydrofolate, leading to DNA damage and cell death, thus directly inhibiting de novo pyrimidine synthesis. ${ }^{1,2}$ Anti-inflammatory effect of MTX might be related to several mechanisms, not all of them are investigated in details. It is being widely used due to its proven efficacy in treating certain inflammatory diseases. Mechanisms contributing to this effect are related to its interference with adenosine, cyclooxygenase/lipoxygenase and cytokines pathways. Methotrexate increases intracellular concentration of 5-aminoimidazole-4-carboxamide ribonucleoside (AICAR) causing competitive inhibition of AMP deaminase and subsequently accumulation of intracellular adenine nucleotides that are converted extracellularly to adenosine. ${ }^{3}$ Adenosine suppresses cytokine and chemokine production and enhances the anti-inflammatory cytokine IL-10 production, thus regulating classical macrophage regulation. ${ }^{4}$ Methotrexate also inhibits prostaglandin PGE2 production, as well as production of leukotriene LTB4, a product of 5-lipoxygenase pathway. ${ }^{5,6}$

\section{USE OF METHOTREXATE IN INFLAMMATORY AND AUTOIMMUNE DISEASES}

Rheumatoid arthritis (RA) is an autoimmune inflammatory disease for whose treatment MTX is the standard of care, approved by the FDA for RA in 1988, although more than 30 years earlier it was already known that RA patients can benefit from MTX therapy. Its role is now well established and benefits numerous patients with the disease. ${ }^{7}$

Inflammatory bowel disease (IBD) is an inflammatory disease characterized by uncontrolled inflammation of epithelial cell lining of the intestine. It is believed that this inflammation is triggered by abnormal intestinal mucosal immune response to environmental triggers. Factors contributing to the disease include gastrointestinal microbiota, diet, the architecture of gut lining cells and genetic factors. Main classification of IBD is into Crohn's disease (CD) and ulcerative colitis (UC), but there is also unclassified IBD (IBD-U), an IBD without features of CD and UC. ${ }^{8}$ There is no known medicine or surgical treatment for the IBD, however anti-inflammatory agents such as corticosteroids, monoclonal antibodies (infliximab, adalimumab, certolizumab, and natalizumab), azathioprine, mercaptopurine and methotrexate are being used to manage symptoms of the disease. ${ }^{9}$ The first results of MTX administration in IBD patients were reported in 1987 by Kozarek, who found that in majority of IBD patients receiving $25 \mathrm{mg}$ MTX intramuscularly for 12 weeks, prednisone doses could be tapered significantly. In some CD patients MTX contributed to mucosal healing. Although some reviews concluded that $25 \mathrm{mg}$ of MTX given i.m. weekly followed by $15 \mathrm{mg}$ of MTX given i.m weekly demonstrates efficacy for induction and maintenance of remission in adult CD patients, official American Gastroenterological Association guideline concludes that MTX is no more effective than placebo to induce remission of CD. In patients with UC there are contrary results regarding MTX as a monotherapy, with additional studies trying to definitely establish efficacy of MTX in CD patients. Currently, MTX is being increasingly used in combination with anti-TNF agents to prevent immunogenicity. ${ }^{10}$

In 1971, a weekly oral schedule of three MTX doses per $24 \mathrm{~h}$ was introduced for the treatment of psoriasis by Weinstein. In this treatment, MTX can be used as a monotherapy or combination therapy. When used as a monotherapy, the response (reduction in PASI) in $70-80 \%$ patients can be achieved in $1-4$ weeks. Combination therapy with other agents, such as cyclosporine or topical agents may be convenient to maintain efficacy while decreasing total cumulative dose and side effects. Biological agents, such as adalimumab and infliximab showed superiority over methotrexate in the treatment of psoriasis. ${ }^{11}$ No close evaluation has been performed on side effects and related risk factors despite almost half century of MTX use in the indication. A retrospective study that collected the data between 2009 and 2014 showed no significant risk factors even after 1 year of MTX use, however elevated transaminases were observed in $20-30 \%$ of patients. These findings were independent of cumulative dose and treatment duration, implying that monitoring for of hepatotoxicity during the MTX treatment should be performed for every patient, regardless of associated comorbidities and health status. ${ }^{12}$

Another disease where MTX therapy finds its place is sarcoidosis. Sarcoidosis is a systemic disease characterized by presence of granulomas in any organ, most often in lungs and intrathoracic lymph nodes. ${ }^{13}$ Chronic sarcoidosis usually refers to disease that has been present in patients for more than 2 years. The first line therapy involves corticosteroids, however in patients that have disease for long time, alternatives are needed. First documented case of MTX use in sarcoidosis patients dates back to ' $60 \mathrm{~s}$. Throughout the years, MTX showed to be better alternative to corticosteroids due to its relative safety and known adverse effects. Even presence of liver disease due to sarcoidosis is not a contraindication to MTX treatment. When starting therapy, effect usually should not be expected for the first six months, a period during which the drug is often administered with corticosteroids. Corticosteroids dose is maintained during this period when tapering begins. Treatment is then continued 
for 2 years at which time MTX is withdrawn. If symptoms show again, MTX is reinstituted as before. The acceptance rate among patients is high, reflecting its better toxicity profile compared with prednisone. ${ }^{14}$

\section{METHOTREXATE COMBINED WITH NANOPARTICLES - FUTURE OF METHOTREXATE USE}

Due to wide use of MTX in different indication and its associated adverse effects, there is a rising need to find better formulation that will improve delivery of the drug to targeted cells and tissues, while decreasing harmful effects on healthy surrounding cells and tissues as well as systemic toxicity. The most interesting research is based on preparation of suitable nanocarriers that will fulfill the expectations set for the targeted delivery. Nanoparticles(NPs) of size between 20 and $200 \mathrm{~nm}$ are considered appropriate, as small NPs with diameter less than $20 \mathrm{~nm}$ can be cleared through renal filtration, while large particles with diameter more than $200 \mathrm{~nm}$ can be rapidly eliminated by the reticuloendothelialsystem. ${ }^{15}$ Research has also been carried on incorporating bile salts in nanoparticles with drugs for oral administration to improve stability and reduce the leakage of the drug in small intestine, considering known effect that bile salts decrease the absorption of methotrexate in rat intestine. ${ }^{16,17}$ Bile acids can play a critical role as drug carriers in the form of chemical conjugates, complexation, mixed micelles formation as well as stabilized bile acid liposomes (bilosomes), and they are considered environmentally safe materials for drug design and delivery. ${ }^{18,19}$

Numerous research studies are carried to optimize MTX therapy and one part of them focuses on nanocarriers filled with the drug. In general, nanocarriers have role in protecting the drug from degradation, improving drug absorption by facilitating diffusion through epithelium and improving intracellular penetration. Nanoparticles are materials with dimensions less than several hundred nanometers and are 2-4 times smaller than human cells. Due to this property, they represent great solution for avoiding unwanted drug effects on surrounding cells and tissues, targeting specifically cells affected by the disease.

One of the nanocarriers widely used is chitosan, a natural polysaccharide derived from chitin by deacetylation. It is biodegradable, biocompatible and non-toxic. Due to its cationic properties, it can form nanoparticles with anionic drugs, such as MTX. Many types of cancer are characterized by overexpression of folate receptors, making MTX a great candidate for use in cancer diagnosis. A study was conducted with goal to prepare a new radiopharmaceutical for breast cancer diagnosis. Methotrexate loaded chitosan nanoparticles were prepared by ionotropic gelation and radiolabeled by Technetium-99m (99mTc). Out of two formulations, one showed better results, with average particle size of $169,000 \pm 10,316 \mathrm{~nm}$, polydispersity index $0.499 \pm$ 0,020 and zeta potential $20.133 \pm 1.144 \mathrm{mV}$, implying that particles were stable according to these parameters. Results demonstrated that radiolabeled MTX loaded chitosan nanoparticles showed two times higher incorporation in breast cancer cells than in normal cells, concluding that they can be used for breast cancer diagnosis in nuclear medicine center after additional research, less harming normal cells than other agents currently used. ${ }^{20}$

Another research aimed at developing topical formulation of MTX-loaded nanostructured lipid carriers (NLCs). In the treatment of psoriasis, MTX is usually administered orally and parenterally as it inhibits epidermal cell proliferation. Sustained drug release over a prolonged period is possible by using drug carriers and nano-dermatology is a field of rising interest due to possibility to maximize therapeutic effect and minimize adverse effect by topical administration of the drug. This way of administration is characterized by the ability of such nano-structures to create a mono layered lipid film on the skin, thus avoiding water evaporation, increasing skin moisture and hydration and resulting in better permeability. High-shear homogenization followed by ultrasound method was applied in preparation of the NLCs, which contained Witepsol S51, oleic acid and polysorbates 60 or 80 . All formulations of MTX-loaded NLCs showed zeta potential between -36 and $-40 \mathrm{mV}$, suggesting good skin permeation and long-term stability, which was proved after 28 days of storage at room temperature. There has been no statistically significant difference in entrapment efficiency between polysorbates 60 and 80 . In vitro MTX release assay showed fast initial phase of drug release of $64 \pm 16 \%$ and $64 \pm 10 \%$, for NLC-P60 and NLC-P80, respectively in the first $2 \mathrm{~h}$, followed by sustained release until $8 \mathrm{~h}$. Although initial phase of drug release is fast, this formulation proved to have great potential for use in psoriasis treatment due to gradual release of the drug, avoiding the loss of therapeutic agent and allowing its enhanced administration through the skin. $^{21}$

Niosome nanoparticles are non-ionic surfactant-based vesicles which can encapsulate both hydrophilic and hydrophobic agents. They have bilayer structure - hydrophilic heads are opposite to aqueous solutions and hydrophobic heads are opposite to organic solutions, allowing them to be much more stable during the formulation process and storage compared to liposomes. In addition, niosomes preparation is cheaper, making them nanoparticles of great interest in pharmaceutical industry. ${ }^{22}$ Scientists have worked on preparing optimal MTX-loaded niosomes for topical administration in psoriasis treatment. Their research demonstrated that the percentage of drug retained in the skin for the nio- 
somal suspension was found to be significantly higher ( $p$ $<0.05$ ) as compared to the drug solution (with equivalent amount of drug) at all-time points. Although further preclinical research on suitable animal models is needed, these results are encouraging and hold promise for developing effective, stable and cheap MTX nanoparticles for topical administration in psoriasis treatment. ${ }^{23}$

Combination chemotherapy and nanoparticles delivery shows great potential in cancer treatment. Abbasi and his colleagues formulated doxorubicin-methotrexate (DOXMTX) nanoparticle combination and performed research in oral squamous cell carcinoma (OSCC) rat model. Study evaluated efficacy of i.v. and oral mode of DOX-MTX loaded nanoparticles compared to free DOX in terms of their potential to affect the expression level of Her2/neu. Both forms demonstrated high performance in affecting Her2 mRNA level, making them interesting for further research as potential therapy that can improve outcome of disease in invasive stages of OCSS. ${ }^{24}$

Lymphatic system has significant role in immune response and cancer metastasis and delivering MTX in the lymphatic system is closely related to immune system. Nano-delivery of the drugs allows for transfer to the lymphatic system through diffusion into the intercellular space of porous lymphatic walls and use of reduced drug dose by maximizing its effect. Numerous research studies focus on in vitro tests, while Jang and colleagues studied MTX-loaded NPs in rats. NPs were prepared using Poly(d,l-lactideco-glycolide) (PLGA) in internal oil phase and poly vinyl alcohol (PVA) in external aqueous phase. The smallest particle size was $110.5 \pm 8.38 \mathrm{~nm}$ when PLGA concentration was $0.5 \%(\mathrm{w} / \mathrm{v})$. In the study, MTX dose of $3 \mathrm{~g}$ was selected for incorporation to NPs due to best particle characteristics, including encapsulation efficiency of $93.34 \pm 0.51 \%$, drug loading of $93.34 \pm 0.51 \%$ and particle size of $163.7 \pm$ $10.25 \mathrm{~nm}$. Zeta potential showed no significant difference between different MTX doses and ranged from -17.3 \pm 2.63 to $-20.4 \pm 1.54 \mathrm{mV}$. NPs had higher antiproliferative effects against cancer cells compared to the control group in in vitro toxicity studies and in vivo they demonstrated different PK characteristics than free MTX, having high lymphatic efficiency with low migration and accumulation in kidney and liver. These NPs represent great potential for effectively delivering MTX to lymphatic system while decreasing chances of adverse effects, most of which are related to its accumulation in kidney and liver. ${ }^{25}$

\section{NEW FORMULATIONS IN TOPICAL ADMINISTRATION OF METHOTREXATE}

As described in previous paragraphs, scientists are working on finding optimal methotrexate formulation for topical administration, considering better safety aspects with less adverse effects, while effect of the drug is still maintained. The main problem with this approach is that methotrexate is hydrosoluble and has limited capacity for passive diffusion at the physiological $\mathrm{pH}$ due to dissociation.

Although methotrexate is usually given orally or parenterally for the treatment of rheumatoid arthritis, there is rising interest to find appropriate topical formulation. Ufasomes were for the first time prepared by Gebicki and Hicks and represent structures that are formed similar to phospholipid liposomes but made from pure long-chain fatty acids, specifically from oleic acid. ${ }^{26}$ As with other small particles, scientists have worked on entrapping MTX into ufasomes for dermatological use. Vesicles were prepared by film hydration method and sonicated to form the uniform size vesicular dispersion. In parallel, plain MTX gel was prepared by using MTX solution into the previously made carbopol gel in a $2: 1$ ratio. The vesicular sizes were obtained in the range of $500 \mathrm{~nm}$ to $1 \mu \mathrm{m}$ and the best entrapment efficiency was observed in the molar quantity $7: 3$ oleic acid to MTX ratio $(51.0 \pm 4.2 \%) \cdot \mathrm{pH}$ of the drug was adjusted to 7.4 to normalize the effect of $\mathrm{pH}$ on skin permeation. Compared to plain gel, a significant increase in permeation was recorded from oleic acid vesicle dispersion - $13 \pm 3 \%$ of MTX permeated through the skin from plain gel, while this percentage increased to $52 \pm 6 \%$ from oleic acid vesicles. Release of MTX from the vesicle was slow, controlled, and uniform as compared to plain drug solution. Sharma and Arora chose this formulation that showed the best results for further research. ${ }^{27}$

Use of a suitable galenic formulation of MTX for topical use might be also a treatment option due to its effects on keratinocytes in the vital epidermis or on inflammatory cells in the dermis. Potential therapeutic benefit was observed in indications like mycosis fungoides (premycotic stage), lymphomatoid papulosis and sequential application in combination with photodynamic therapy for actinic keratosis. Wohlrab and his colleagues wanted to develop an extemporaneous preparation that will be readily available and quality assured for use by physicians. In addition to a classic hydrogel, a tricoherent, amphiphilic cream (with and without penetration promoter) and micro-emulsion systems of the $\mathrm{O} / \mathrm{W}$ and $\mathrm{W} / \mathrm{O}$ type were examined. The analyses were conducted on four skin biopsies from a single donor. Release of MTX was significantly higher from the studied microemulsion systems than from the amphiphilic cream ("Basiscreme DAC"), however penetration tests showed that after the 
application of amphiphilic cream, bioavailability of MTX in vital epidermis and corium, the relevant target compartments, is the highest. The drug was sufficiently stable in all analyzed preparations. Based on the study results, authors recommended following prescription: Methotrexate (acid form) 0.25/0.5 g and "Basiscreme DAC" ad 100.0 g.

There are few reported allergy reactions to systemic administration of the MTX, but there is no sufficient information to rule out potential reaction after topical use. However, available data does not suggest any relevant sensitization potential for MTX. ${ }^{28}$ To be able to develop optimal MTX topical formulation, one should also think of suitable bioadhesive surfactant systems for skin delivery, such as liquid crystalline systems (LCSs) and microemulsions (MEs). They contain glycol copolymer-based silicone fluid (SFGC) as oil phase, polyether functional siloxane (PFS) as surfactant, and carbomer homopolymer type A (C971) dispersion at $0.5 \%$ (wt/wt) as aqueous phase. Group of researchers at Sao Paulo State University developed MTX-loaded LCSs and MEs and characterized them using polarized light microscopy, small angle $\mathrm{X}$ ray scattering, rheological studies, and bioadhesion assays. The study concluded that the proposed systems are suitable for the controlled release of MTX, with convenient texture profile and bioadhesion. Methotrexate was released faster when incorporated in ME rather than in LCS. The study also demonstrated that MTX-unloaded LCS and microemulsion are not cytotoxic, thus presenting additional potential formulation of MTX in topical administration. ${ }^{29}$

\section{CONCLUSION}

Considering wide MTX use in treatment of various oncological and inflammatory diseases and its associated adverse effects, there is rising interest in finding optimal pharmaceutical formulations which will maintain MTX efficacy while avoiding adverse effects. Current research is mainly focused on incorporating MTX in nanoparticles for parenteral and oral administration, while there is also increase in number of research studies done with topical preparations of the drug. Nanoparticles protect the drug from degradation and improve absorption allowing targeted delivery of the drug. Although one would not expect topical administration of MTX to be unsafe, there is no sufficient information to rule out possible allergy reactions and further research is needed. There is a lot of in vitro and in vivo data of MTX characteristics and efficacy in nano-formulations, however next steps should be clinical studies in human that will confirm findings from preclinical research.

\section{ACKNOWLEDGMENT}

This research was supported by HORIZON2020 MEDLEM project No.690876 and the Project for Scientific and Technological Development of Vojvodina No. 114-4512072-/2016-02.

\section{CONFLICT OF INTEREST}

All authors have no conflicts of interest that are relevant to the content of this review.

\section{LIST OF ABBREVIATIONS}

AAICAR - 5-aminoimidazole-4-carboxamide ribonucleoside

AMP - adenosine monophosphate

CD - Crohn's disease

IBD - inflammatory bowel disease

IBD-U - unclassified inflammatory bowel disease

LCS - liquid crystalline system

$\mathrm{ME}$ - micro emulsion

MTX - methotrexate

NLC - nanostructured lipid carriers

$\mathrm{NP}$ - nanoparticle

OSCC - oral squamous cell carcinoma

PASI - psoriasis area and severity index

PFS - polyether functional siloxane

PLGA - Poly(d,l-lactide-co-glycolide)

PVA - poly vinyl alcohol

RA - rheumatoid arthritis

TNF - tumor necrosis factor 


\section{REFERENCES}

1. Neradil J, Pavlasova G, Veselska R.New mechanisms for an old drug; DHFR- and non-DHFR-mediated effects of methotrexate in cancer cells. Klin Onkol 2012; 25(Suppl 2): 2S87-92.

2. Chen G, Fawcett JP, Mikov M, Tucker IG.Simultaneous determination of methotrexate and its polyglutamate metabolites in Caco-2 cells by liquid chromatography-tandem mass spectrometry. J Pharm Biomed Anal 2009; 50: 262-6.

3. Montesinos MC, Takedachi M, Thompson LF, Wilder TF, Fernández P, Cronstein BN. The antiinflammatory mechanism of methotrexate depends on extracellular conversion of adenine nucleotides to adenosine by ecto-5'-nucleotidase: findings in a study of ecto-5'-nucleotidase genedeficient mice. Arthritis Rheum 2007; 56: 1440-5.

4. Haskó G, Cronstein B. Regulation of inflammation by adenosine. Front Immunol 2013; 4: 85.

5. Vergne P, Liagre B, Bertin P, et al. Methotrexate and cyclooxygenase metabolism in cultured human rheumatoid synoviocytes. J Rheumatol 1998; 25: 433-40.

6. Sperling RI, Benincaso AI, Anderson RJ, Coblyn JS, Austen KF, Weinblatt ME. Acute and chronic suppression of leukotriene B4 synthesis ex vivo in neutrophils from patients with rheumatoid arthritis beginning treatment with methotrexate. Arthritis Rheum 1992; 35: 376-84.

7. Weinblatt ME. Methotrexate in rheumatoid arthritis: a quarter century of development. Trans Am Clin Climatol Assoc 2013; 124: 16-25.

8. Nemati S, Teimourian S. An overview of inflammatory bowel disease: general consideration and genetic screening approach in diagnosis of early onset subsets. Middle East J Dig Dis 2017; 9: 69-80.

9. Fakhoury M, Negrulj R, Mooranian A, Al-Salami $\mathrm{H}$. Inflammatory bowel disease: clinical aspects and treatments. J Inflamm Res 2014; 7: 113-20.

10. Herfarth HH, Kappelman MD, Long MD, Isaacs KL. Use of methotrexate in the treatment of inflammatory bowel diseases (IBD). Inflamm Bowel Dis 2016; 22: 224-33.

11. Cipriani P, Ruscitti P, Carubbi F, Liakouli V, Giacomelli R. Methotrexate: an old new drug in autoimmune disease. Expert Rev Clin Immunol 2014; 10: 1519-30.
12. Kim BR, Ohn J, Choi CW, Youn SW. Methotrexate in a real-world psoriasis treatment: is it really a dangerous medication for all? Ann Dermatol 2017; 29: 346-8.

13. Soto-Gomez N, Peters JI, Nambiar AM. Diagnosis and management of sarcoidosis. Am Fam Physician. 2016; 93: 840-8.

14. Baughman RP, Lower EE. A clinical approach to the use of methotrexate for sarcoidosis. Thorax 1999; 54: 742-6.

15. Jang JH, Jeong SH, Lee YB. Preparation and In Vitro/ In Vivo Characterization of Polymeric Nanoparticles Containing Methotrexate to Improve Lymphatic Delivery. Int J Mol Sci 2019; 20: 3312.

16. Arafat M, Kirchhoefer C, Mikov M, Sarfraz M, Löbenberg R. Nanosized liposomes containing bile salt: a vesicular nanocarrier for enhancing oral bioavailability of BCS class III drug. J Pharm Pharm Sci 2017; 20: 305-18.

17. Chen G, Fawcett JP, Mikov M, Tucker IG. Monoketocholate can decrease transcellular permeation of methotrexate across Caco- 2 cell monolayers and reduce its intestinal absorption in rat. J Pharm Pharmacol 2009; 61: 953-9.

18. Kecman S, Škrbić R, Badnjevic Cengic A, Mooranian A, Al-Salami H, Mikov M, Golocorbin-Kon S. Potentials of human bile acids and their salts in pharmaceutical nano delivery and formulations adjuvants. Technol Health Care 2020; 28: 325-335.

19. Parezanović GŠ, Lalic-Popovic M, Golocorbin-Kon S, Vasovic V, Milijašević B, Al-Salami H, Mikov M. Environmental transformation of pharmaceutical formulations: a scientific review. Arch Environ Contam Toxicol 2019; 77: 155-161.

20. Ekinci M, Ilem-Ozdemir D, Gundogdu E, Asikoglu M. Methotrexate loaded chitosan nanoparticles: Preparation, radiolabeling and in vitro evaluation for breast cancer diagnosis. J Drug Deliv Sci Technol 2015; 30: 107-13.

21. Pinto MF, Moura CC, Nunes C, Segundo MA, Costa Lima SA, Reis S. A new topical formulation for psoriasis: development of methotrexate-loaded nanostructured lipid carriers. Int J Pharm 2014; 477: 519-26.

22. Ge X, Wei M, He S, Yuan WE. Advances of non-ionic surfactant vesicles (niosomes) and their application in drug delivery. Pharmaceutics 2019; 11: 55. 
23. Abdelbary AA, AbouGhaly MH. Design and optimization of topical methotrexate loaded niosomes for enhanced management of psoriasis: application of BoxBehnken design, in-vitro evaluation and in-vivo skin deposition study. Int J Pharm 2015; 485: 235-43.

24. Abbasi MM, Monfaredan A, Hamishehkar H, Jahanban-Esfahlan R. New formulated "DOX-MTX-loaded nanoparticles" down- regulate HER2 gene expression and improve the clinical outcome in OSCCs model in rat: the effect of IV and oral modalities. Asian Pac J Cancer Prev 2014; 15: 9355-60.

25. Jang JH, Jeong SH, Lee YB. Preparation and in vitro/ in vivo characterization of polymeric nanoparticles containing methotrexate to improve lymphatic delivery. Int J Mol Sci 2019; 20: 3312.

26. Gebicki JM, Hicks M.Ufasomes are stable particles surrounded by unsaturated fatty acid membranes. Nature 1973; 243:2 32-4.

27. Sharma A, Arora S.Formulation and in vitro evaluation of ufasomes for dermal administration of methotrexate. ISRN Pharm 2012; 2012: 873653.

28. Wohlrab J, Neubert RH, Michael J, Naumann S.Methotrexate for topical application in an extemporaneous preparation. J Dtsch Dermatol Ges 2015; 13: 891-901.

29. Cintra GA. Bioadhesive surfactant systems for methotrexate skin delivery. Molecules 2016; 21: 231. 